\title{
The Acquisition of the English Plural Morphemes by Arabic-Speaking EFL Learners
}

Safaa M. Altarawneh, Maram H. Hajjo

English Language Teacher Education, Al Ain University of Science and Technology, Al Ain, UAE

Corresponding author: Safaa M. Altarawneh, Al Ain University of Science and Technology, Email: s-a-f-a1@hotmail.com

\section{ARTICLE INFO}

Article history

Received: March 13, 2018

Accepted: April 14, 2018

Published: April 30, 2018

Volume: 6 Issue: 2

Conflicts of interest: None

Funding: None

\begin{abstract}
This research paper analyzes the extent to which Arabic-speaking EFL learners are aware of the English plural morphemes and whether they are able to recognize them in context. The study also investigates whether the participants' English proficiency level may play a role in their ability to recognize these morphemes. For the purpose of the study, we designed a Grammaticality Judgment Task (GJT), which was by sixty students from Al Ain University of Science and Technology, Al Ain, The United Arab Emirates (UAE), to elicit data. The sentences used in the test were adapted and modified from the Corpus of Contemporary American English (COCA) in order to suit the students' English proficiency level. The results revealed that there is a little awareness of the English plural morphemes among Arabic-speaking EFL learners. In addition, the participants' English proficiency level had a little effect on the participants' use of English plural morphemes. Finally, the paper concluded with some pedagogical implications and recommendations for further research.
\end{abstract}

Key words: English Plural Morphemes, Second Language Acquisition, Arabic-speaking EFT Learners

\section{INTRODUCTION}

The acquisition of the morphological system of the target language can be regarded as an essential skill that ESL/EFL learners need to have in their arsenal in order to enhance their communicative skills and, in turn, communicate effectively with native speakers of the target language (see Ekiert, 2005). Acquisition of both derivational and inflectional morphemes has not been given due attention, especially with regard to the acquisition of these morphemes by Arabic-speaking EFL learners (Altakhaineh and Zibin, 2017). Thus, more studies are needed in this area to shed light on the difficulties encountered by Arabic-speaking EFL learners in the acquisition process of English morphemes. Recently, the acquisition of the English plural morphemes by non-native-speaking learners has started to capture researchers' attention. As a result, this study examines the extent to which Arabic-speaking EFL learners are aware of English plural morphemes.

\section{Objectives}

The main goals of the current study are to

1. investigate whether Arabic-speaking EFL learners' English proficiency levels play a role in their use of regular and irregular plurals in English; and

2. determine whether Arabic-speaking EFL learners encounter certain difficulties with certain types of plurality in English.

\section{Research Questions}

This study is an attempt to seeking answers to the following research questions:

1. Does the English proficiency level of Arabic-speaking EFL learners play a role in their awareness of regular and irregular plural morphemes in English?

2. Do they encounter certain difficulties with certain types of plural morphemes in English? If so, why?

\section{GENERAL BACKGROUND}

\section{Plural Morphemes in English}

There are two types of plural morphemes in English, namely, the regular plural morpheme and the irregular plural morpheme (Lieber, 2015). The former is suffixed to the end of most nouns. In normal cases, the plural form can be realized by adding an $-s$ or $-e s$ to the end of the noun stem, e.g. rabbit vs. rabbits (Aarts, Chalker, and Weiner, 2014):

1. $\quad$ cat $=$ cats

2. $\operatorname{dog}=\operatorname{dogs}$

3. box $=$ boxes

4. $\operatorname{dish}=$ dishes

5. baby $=$ babies

6. candy $=$ candies

7. knife $=$ knives

8. wife $=$ wives

9. $\quad$ studio $=$ studios 
However, there are some exceptions, where the plural is not realized by simply adding an $s$ to the stem, but rather by modifying the stem: foot vs. feet. The latter is a case of an irregular plural morpheme. There are some common types of irregular plurals that occur (Aarts et al. 2014). For instance, certain nouns have the same form for both singular and plural. Most of these nouns are types of animals, as in:

10. deer $=$ deer

11. fish $=$ fish

12. moose $=$ moose

In words that end in "us", the latter is changed into an "i", especially if it comes from a Latin word (see examples 13-14). There are many exceptions to this rule and it is becoming more acceptable to add "es" instead of changing to " $i$ ".

13. fungus $=$ fungi

14. syllabus $=$ syllabi

In words that end in "is", the latter is changed into "es", as in:

15. hypothesis $=$ hypotheses

16. oasis $=$ oases

17. crisis $=$ crises

Nouns that end in "um" often become plural by changing "um" to "a", as in:

18. bacterium $=$ bacteria

19. medium $=$ media

20. curriculum $=$ curricula

Finally, certain words do not add a suffix to the end, but instead change the word itself. Some examples are as follows:

21. $\operatorname{man}=$ men

22. foot $=$ feet

23. tooth $=$ teeth

24. goose $=$ geese

It can be argued, here, that irregular plural morphemes can be learned through listening and reading activities that include many words whose plural is irregular. Through listening, speaking and reading, learners would have a higher chance to encounter such words (Krashen, 2004). The following section reviews some studies that examined the acquisition of plural morphemes.

\section{Previous Studies on the Acquisition of Plural Morphemes}

It seems that certain studies have been conducted on the acquisition of inflectional morphemes in many languages. For instance, in their study, Clahsen, Rothweiler, Woest, and Marcus (1992) investigated the acquisition of German noun plural in terms of how children represent regular and irregular inflectional morphemes. In another study, Pinker and Prince (1992) examined the acquisition of inflectional morphemes by German-speaking children. The results of their study revealed that overgeneralization is the main source of error. Specifically, children have the tendency to overgeneralize a certain suffix, e.g. - s and apply it to different stems.

In relation to second language acquisition, Luk and Shirai (2009) explained that several researchers in the relevant literature have argued that the first language of learners does not have a noticeable impact on the acquisition of morphemes (e.g., Ellis, 1994; Myles and Mitchell, 2004). Nonetheless, Luk and Shirai (2009) indicated that this assumption has not been systematically investigated. Hence, the two researchers analyzed studies that have been conducted on the acquisition of English morphemes by native speakers of Korean, Chinese, Japanese and Spanish in order to explore the impact of L1 on the acquisition of these morphemes. The review demonstrated that L1 does have an effect on the acquisition of English morphemes. For example, the acquisition of English morphemes by Spanish L1 learners is in line with the natural order of acquisition as stated by Krashen (1977). On the other hand, native speakers of Chinese, Japanese, and Korean mainly acquire plural $-s$ and articles later and the possessive - 's earlier than stipulated by the natural order. Such a result proposes that L1 can have an effect on the acquisition of English morphemes and that acquisition may not conform to the natural order relying on the absence or presence of the same category in the learners' L1. This result also suggests that the effect of L1 in the acquisition of morphemes is stronger than predicted in earlier research.

In another relevant study, Jia (2003) explains that even though the acquisition of the English plural morphemes by L1 learners, specifically English speaking EFL learners, has been extensively studied, this type of acquisition by L2 learners has not been given due attention. Thus, Jia (2003) conducted a study to explore the similarities and difference between L1 and L2 as far as the English plural morphemes are concerned. Ten native Mandarin-speaking children who left China for the United States between the ages of five and sixteen were examined for five years. Data was elicited from the participants via a picture description task and spontaneous speech. The results demonstrated that only seven out of the ten L2 learners mastered the English plural morphemes even after five years of exposure to English. This result was compared to L1 learners who are able to master the English plural morphemes within 3 years. Jia (2003) suggested that the language environment and the age of initial exposure to English can explain some differences between the two groups. The speech of the ten L2 learners showed that same error types produced by L1 learners, yet, L2 learners marked the same noun inconsistently and frequently in the same testing session. In addition, the L2 learners overgeneralized the plural morpheme in mass noun contexts and in singular contexts. One may also argue here that similar to the results of Luk and Shirai (2009), L1could have played a role in the performance of L2 learners in comparison with the L1 learners.

Drawing on the above literature, it seems that the acquisition of English morphemes by L2 speakers has not been given due attention. Other researchers investigated the acquisition of various linguistic phenomena by Arabic-speaking EFL learners, such as culturally-loaded words (Altakhaineh and Zibin, 2014), metaphorical expressions (Zibin, 2016a, 2016b), collocations (Alsulayyi, 2015), and polysemy (AlNamir, 2017). However, the acquisition of regular and irregular plural morphemes by adult Arabic-speaking EFL learners has been given little attention. Thus, studying the acquisition of plural morphemes in English is an area worthy of investigation. 
The following section discusses the sample and methods of data collection adopted in the current study.

\section{METHODOLOGY}

\section{Sample}

The participants in this study were sixty students at Al Ain University of Science and Technology, Al Ain, The United Arab Emirates (UAE). All participants were Arabic- speaking EFL learners, whose mean age was 19. They were enrolled in Intensive Remedial English (IRE) course and English 1 course. The participants were chosen randomly and divided into groups. The classification of the participants was based on their English proficiency levels. In particular, the participants were divided into two groups: 30 beginner learners and 30 intermediate learners. The basis of classification depended on their IELTS scores: those who got 3 or 3.5 were treated as beginner, while those who got 4 or 5.5 were treated as intermediate (see Altakhaineh and Zibin, 2017).

We informed the participants that their participation in the study is optional and that they are free to withdraw their consent to participate whenever they want without any consequences. Finally, we expressed our gratitude to the participants for taking part in the study.

\section{Data Collection}

The data elicitation tool employed in this study was Grammaticality Judgment Task (GJT). Other researchers employed a Grammaticality Judgment Task (GJT) to elicit data in the field of second language acquisition (see Appendix A), e.g. Zibin and Altakhaineh (2016). Grammaticality judgments operate on the performance-competence interface and test whether constituents are grammatical or ungrammatical (Fetzer 2004). Fetzer stated that grammaticality judgments are made of either of two domains: they are either based on the premise of linguistic competence, i.e. speakers have knowledge of a language and know how to identify grammatical and ungrammatical sentences, or they are confronted with language material in an idealized manner. We tested the validity of using this type of data collection tool by giving the first copy of the GJT to two British native speakers, two linguists and two professors who are specialized in linguistics. We selected the sentences in the GJT used in the current study on the basis of their answers. The GJT, which is a modified version of Zibin and Altakhaineh (2016), consisted of a total of 20 items, including 10 regular plural nouns; 10 irregular plural nouns. The full list of nouns in the GJT was as follows:

1) Regular plural nouns $(\mathrm{n}=10)$ cats, boys, boxes, ladies, cars, pencils, toys, leaves, houses

2) Irregular plural nouns $(\mathrm{n}=10)$

feet, cacti, deer, phenomena, oases, children, mice, sheep, crises, criteria

The basis of selecting the nouns used in the GJT relied on the frequency of these nouns in the Corpus of Contemporary American English (COCA). The aim of this procedure was to ensure that these nouns are used in contemporary speech (see Zibin 2016a, 2016b). No minimum frequency level was established. However, the frequency was taken into consideration in the discussion of the results. Table 1 shows the frequency of the regular plural nouns in COCA and Table 2 presents the frequency of the irregular plural nouns in COCA.

Tables 1 and 2 show that the variation of the frequency of the nouns ranged between 309,001 and 195. This shows that some nouns are used more frequently than others. This frequency is examined in the next section to determine whether it had an impact on the participants' answers on the test.

\section{RESULTS AND DISCUSSION}

The aim of this research was to determine whether the participants' English proficiency level had any impact on the participants' awareness of the English plural morphemes. Specifically, it aimed to determine whether there was a noticeable difference between beginner learners and intermediate learners in terms of using regular and irregular plural nouns. The study included 600 judgments and there were $55 \%$ accurate responses. The results revealed the numbers and the percentages of the extent of awareness for each

Table 1. The frequency of the regular plural nouns included in the GJT in the COCA

\begin{tabular}{lc}
\hline $\begin{array}{l}\text { Regular plural } \\
\text { nouns }\end{array}$ & $\begin{array}{c}\text { Frequency of the nouns } \\
\text { in the COCA }\end{array}$ \\
\hline Cats & 9,282 \\
Boys & 59,817 \\
Boxes & 14,567 \\
Ladies & 16,814 \\
Cars & 46,065 \\
Pencils & 1,742 \\
Toys & 10,349 \\
Leaves & 44,348 \\
Houses & 32,470 \\
Axes & 1,376 \\
\hline
\end{tabular}

Table 2. Frequency of the irregular plural nouns included in the GJT in the COCA

\begin{tabular}{lc}
\hline $\begin{array}{l}\text { Irregular plural } \\
\text { nouns }\end{array}$ & $\begin{array}{c}\text { Frequency of the nouns } \\
\text { in the COCA }\end{array}$ \\
\hline Feet & 110,485 \\
Cacti & 504 \\
Deer & 15,446 \\
Phenomena & 5,054 \\
Oases & 195 \\
Children & 309,001 \\
Mice & 7,266 \\
Crises & 4,565 \\
Criteria & 16,716 \\
Sheep & 8,701 \\
\hline
\end{tabular}


group. Table 3 shows that intermediate learners are aware of regular plural nouns, whereas the beginner learners are less aware of some regular plural nouns. Thirty beginner participants scored $47 \%$ on regular plural nouns, but 30 intermediate participants scored $62 \%$ on regular plural noun.

As observed from the table above, there are three important results. First of all, the total average of beginner learners (47) was below the passing average $(50 \%)$. This average shows the general lack of understanding of regular plural morphemes by beginner students. The students scored low regarding the nouns *axes, *toys, *pencils, *houses, and *leaves with the percentages $23 \%, 27 \%, 37 \%, 40 \%, 47 \%$, respectively. It is possible that beginner learners provided accurate answers on these nouns incorrectly because they may not know the rules of forming regular nouns. One may expect here that the ability of EFL learners to know the regular plural nouns would be better. However, the results show the opposite. For example, they thought that the plural of toy is toies. This could be because they may not know that they should not change $y$ to $i$ if there is a vowel before $y$. In addition, they thought that the plural of house is similar to that of mouse. It could be argued that overgeneralization of the rules of forming English noun plurals may have been at play here. That is, because house is spelled similarly to mouse, beginner learners assumed that they would have the same plural. The same may apply to toies, beginner learners may have overgeneralized the rule which changes y into I at the end of some nouns, e.g. ladies. This result is similar to that of Jia (2003), who argued that EFL learners may overgeneralize rules related to the formation of the English plural morphemes.

Secondly, the total average of intermediate learners (62) was above the passing average (50\%). This average shows that intermediate participants performed better than the beginners. The intermediate participants did better with words, such as boys $(83 \%)$, cars $(77 \%)$, boxes $(70 \%)$, pencils $(67 \%)$, cats $(63 \%)$ and ladies $(60 \%)$ in comparison with axes $(50 \%)$, toys $(50 \%)$, houses $(50 \%)$ or leaves $(50 \%)$. Some stu-

Table 3. Frequency and percentage of correct answers on regular plural nouns

\begin{tabular}{lcccccc}
\hline \multirow{2}{*}{$\begin{array}{l}\text { Regular } \\
\text { plural nouns }\end{array}$} & \multicolumn{2}{c}{$\begin{array}{c}\text { Beginner } \\
\text { students }\end{array}$} & & \multicolumn{2}{c}{$\begin{array}{c}\text { Intermediate } \\
\text { students }\end{array}$} & Average \% \\
\cline { 2 - 3 } & $\mathbf{f}$ & $\mathbf{\%}$ & & $\mathbf{f}$ & $\mathbf{\%}$ & \\
\hline Cars & 20 & 67 & & 23 & 77 & 72 \\
Boxes & 18 & 60 & & 21 & 70 & 65 \\
Boys & 21 & 70 & & 25 & 83 & 77 \\
Axes & 7 & 23 & & 15 & 50 & 37 \\
Ladies & 15 & 50 & & 18 & 60 & 55 \\
Toys & 8 & 27 & & 15 & 50 & 39 \\
Houses & 12 & 40 & & 15 & 50 & 45 \\
Leaves & 14 & 47 & & 15 & 50 & 49 \\
Pencils & 11 & 37 & 20 & 67 & 52 \\
Cats & 15 & 50 & 19 & 63 & 57 \\
Overall & & 47 & & 62 & 55 \\
\hline
\end{tabular}

dents answered incorrectly, possibly, they confused the rules of regular plural morphemes. For example, some students thought that the plural of leaf is leafs; thus, they may have forgotten that they have to change $f$ to $v$ and add es. Despite their high frequency in COCA, some regular English plural nouns, e.g. leaves constituted a challenge to the intermediate learners. One may argue here that some of these nouns may not be frequent in the material these participants are exposed to. This may explain the low percentage of correct answers on such nouns.

Finally, as it can be easily noticed from Table 3, both participants scored the highest percentage on the word boys. This may have been due to its high frequency in COCA (see Table 1). It can also be attributed to the high frequency of the word boys in the material these participants study at school or university. Additionally, both groups scored the lowest percentage on the word axes. It can be proposed that such low percentage can be ascribed to the low frequency of axes in COCA (see Table 1). Table 4 below shows the numbers and the percentages of accurate judgments on irregular plural nouns.

Table 4 shows the accurate answers of beginners and intermediate participants concerning irregular plural nouns. It is notable that the intermediate participants performed better than beginner participants. Both beginners and intermediate learners' highest score was on the noun feet, where learners' percentage was $67 \%$ and $77 \%$ respectively. The high percentage of feet may be due its high frequency in modern speech as shown in Table 1, or its high frequency in the material to which students are exposed. The beginners' lowest performance was in the nouns * phenomena, *sheep and * cacti with the percentage $8 \%$. The intermediate learners' lowest performance was in the noun oases where learners' percentage was $40 \%$. The low percentage of oases may be due to its low frequency in COCA or in the material to which students are exposed. Furthermore, one may argue here that the rules related to the irregular plural morphemes may not have been explained to

Table 4. Frequency and percentages of correct answers on irregular plural nouns

\begin{tabular}{lccccc}
\hline \multirow{2}{*}{$\begin{array}{l}\text { Irregular } \\
\text { plural nouns }\end{array}$} & \multicolumn{2}{c}{$\begin{array}{c}\text { Beginner } \\
\text { students }\end{array}$} & \multicolumn{2}{c}{$\begin{array}{c}\text { Intermediate } \\
\text { students }\end{array}$} & Average \% \\
\cline { 2 - 5 } & f & \% & f & \% & \\
\hline Feet & 20 & 67 & 23 & 77 & 72 \\
Deer & 10 & 33 & 16 & 53 & 35 \\
Phenomena & 8 & 27 & 19 & 63 & 45 \\
Sheep & 8 & 27 & 19 & 63 & 45 \\
Children & 12 & 40 & 20 & 67 & 54 \\
Mice & 13 & 43 & 23 & 77 & 60 \\
Criteria & 16 & 53 & 17 & 57 & 55 \\
Crises & 12 & 40 & 17 & 57 & 49 \\
Oases & 9 & 30 & 12 & 40 & 35 \\
Cacti & 8 & 27 & 15 & 50 & 39 \\
Overall & & 39 & & 60 & 50 \\
\hline
\end{tabular}


the participants; hence, the answers produced on the test were faulty.

In addition, to overgeneralization of rules and low frequency in the COCA or in the material to which students are exposed, it can be proposed that some of the difficulties which the participants faced could be due to the differences between the morphological system of English and Arabic, i.e. L2 and L1 (see Jia 2003; Altakhaineh and Zibin 2017). Specifically, while the Arabic morphological system can be both concatenative and non-concatenative, the English morphological system is concatenative. The latter can be defined as a kind of morphological analysis that relies on stringing morphemes together via affixation, while the former can be defined as a kind of morphological analysis that involves modifying the root (see Altakhaineh 2014: 12-13). In Arabic, some examples of concatenative morphology, e.g. the regular masculine plural suffix -uun in the word muslim 'Muslim'/ muslim-uun 'Muslims' can be cited (Altakhaineh 2014: 13). Conversely, a substantial number of examples in Arabic are non-concatenative, such as the root/k-t-b/, denoting a sense of writing, has different forms, yet semantically-related meanings as in katab 'he wrote', kitaab 'book', maktuub 'written', and kaatib 'writer' (Altakhaineh 2014: 14). Thus, the differences in the morphological systems between English and Arabic could be another reason causing errors produced on the test. This argument can be supported by the low percentage of correct answers produced by both groups on regular and irregular plural nouns on the test.

\section{CONCLUSION AND RECOMMENDATIONS}

This research paper has analyzed the extent to which Arabic-speaking EFL learners are aware of the English plural morphemes. It has also examined whether these learners are able to recognize these morphemes in context. The study has also examined whether the English proficiency level of the participants can affect their ability to recognize these morphemes. To this end, a Grammaticality Judgment Task (GJT) was designed to elicit data. The participants were asked to indicate whether the sentences are grammatically correct or not. The sentences used in the test were modified from the Corpus of Contemporary American English (COCA) to be suitable for the participants' English proficiency level. The results demonstrated that Arabic-speaking EFL learners had little awareness of the English plural morphemes whether regular or irregular. In addition, the participants' English proficiency level had little effect on their use of English plural morphemes. The errors produced by both groups of participants were attributed to the differences between the English morphological system and that of Arabic (the participants' first language), overgeneralization of certain rules related to the formation of English plural nouns, and the frequency of the nouns in COCA or in the material to which the participants are exposed. Based on these results, ESL/EFL teachers need to encourage students to read more material to get more exposed to English nouns. Teachers may also be advised to integrate more active learning activities inside the classroom, such as word puzzles and think-pair-share to enhance students' understanding of the English morphological system.
Finally, due to the lack of studies on the acquisition of the English morphological system by Arabic-speaking EFL learners, it is recommended that the acquisition of word formation processes such as compounding by Arabic-speaking EFL learners needs to be examined (Altakhaineh, 2016, 2017).

\section{ACKNOWLEDGEMENTS}

We would like to thank Dr. Abdel Rahman Mitib Altakhaineh not only for his insightful comments and discussion on early drafts of this paper, but also for teaching us the main research skills needed to conduct research papers in linguistics. We would also like to thank all the participants who agreed to take part in this study.

\section{REFERENCES}

Aarts, B; Chalker, S; and Weiner, E. (2014). The Oxford Dictionary of English Grammar: 1000 Entries. Oxford University Press.

Alnamer, S. A. S. (2017). On the Awareness of English Polysemous Words by Arabic-Speaking EFL Learners. $A d$ vances in Language and Literary Studies, 8(2), 112-121.

Alsulayyi, M. N. (2015). The use of grammatical collocations by advanced Saudi EFL learners in the UK and KSA. International Journal of English Linguistics, $5(1), 32$.

Altakhaineh, A.R. M. and Zibin, A. (2014). Perception of culturally loaded words by Arab EFL learners. International Journal of Linguistics, 6(3), 1-22.

Altakhaineh, A. R. M. (2014). The Interaction between Inflection and Derivation in English and MSA. Germany: LAP Lambert Academic Publishing.

Altakhaineh, A. R. M. (2016). Identifying Arabic compounds other than the Synthetic Genitive Construction. Acta Linguistica Hungarica, 63(3), 277-298.

Altakhaineh, A. R. M. (2017). Arabic compounds within the cross-linguistic compound taxonomy of Scalise and Bisetto (2009). Lingue e Linguaggio, 16(1), 101-118.

Altakhaineh, A. R. M. and Zibin, A. (2017). The effect of incidental learning on the comprehension of English affixes by Arabic-speaking EFL learners: acquisition and application. Research in Language, 15(4), 405-423.

Clahsen, H., Rothweiler, M., Woest, A., \& Marcus, G. F. (1992). Regular and irregular inflection in the acquisition of German noun plurals. Cognition, 45(3), 225-255.

Ekiert, M. (2005). Acquisition of the English article system by speakers of Polish in ESL and EFL settings. Working Papers in TESOL \& Applied Linguistics, 4(1), 1-23.

Ellis, R. (1994). The Study of Second Language Acquisition. Oxford: Oxford University Press.

Jia, G. (2003). The acquisition of the English plural morpheme by native Mandarin Chinese-speaking children. Journal of Speech, Language, and Hearing Research, 46(6), 1297-1311.

Krashen, S. (1977). The monitor model for adult second language performance. Viewpoints on English as a Second Language, 152-161. Reprinted in K. Croft (Ed.) Readings in English as a Second Language. New York: 
Winthrop. Translated into Italian and reprinted in $\mathrm{R}$. Titone (Ed.) 1981. Avamposti della Psicolinguistica Applicata. Armando.

Krashen, S. (2004). The Power of Reading. Englewood, CO: Libraries Unlimited.

Lieber, R. (2015). Introducing Morphology. Cambridge: Cambridge University Press.

Luk, Z. P. S. and Shirai, Y. (2009). Is the acquisition order of grammatical morphemes impervious to L1 knowledge? Evidence from the acquisition of plural-s, articles, and possessive's. Language Learning, 59(4), 721-754.

Myles, F. and Mitchell, R. (2004). Using information technology to support empirical SLA research. Journal of Applied Linguistics, 1(2), 169-196.
Pinker, S. and A. Prince. (1992). Regular and Irregular Morphology and the Psychological Status of Rules of Grammar. Proceedings of the 17th Annual Meeting of the Berkeley Linguistics Society. Berkeley, CA: Berkeley Linguistics Society.

Zibin, A. (2016a). On the Production of Metaphors and Metonymies by Jordanian EFL Learners: Acquisition and Implications. Topics in Linguistics, 17(2), 41-58.

Zibin, A. (2016b). The Comprehension of Metaphorical Expressions by Jordanian EFL Learners. SAGE Open, 6(2), 1-15.

Zibin, A. and Altakhaineh, A. R. M. (2016). Acquiring the English causative alternation: Evidence from the University of Jordan. International Journal of Applied Linguistics and English Literature, 5(3), 7-15.

\section{APPENDIX}

\section{Appendix A}

\section{Grammatically Judgment Task}

Please read the sentences below, and then put a tick $(\checkmark)$ next to any sentence you think grammatical and a cross (x) next to any sentence you think ungrammatical. Your first decision is the one we want. Please do not change your answers

\begin{tabular}{ll}
\hline 1 & Cats don't like water. \\
2 & We found all boxen empty. \\
3 & John hates to get his feet wet. \\
4 & Tom told the boys to line up. \\
5 & Your penciles need sharpening. \\
6 & We didn't see many deer in the forest. \\
7 & He used many axes to cut the trees. \\
8 & There are many interesting natural phenomena. \\
9 & Lambs are baby sheeps. \\
10 & I didn't hear any cars. \\
11 & I can't stand noisy childrens. \\
12 & The two ladies smiled at each other. \\
13 & Tom owns two hices and a boat. \\
14 & The field mouses were eating up the farmer's grain. \\
15 & We saw what looked like oases in the desert. \\
16 & Pick up all your toyes and put them away. \\
17 & Motivation is one of the principal criterions for success in learning \\
18 & a second language. \\
19 & Cacti are plants that live in dry places. \\
20 & He is the kind person who copes well in all crisises. \\
\hline
\end{tabular}

